\title{
Common wintering of black kites (Milvus migrans migrans) in Greece, and new data on their wintering elsewhere in Europe
}

\author{
Bežné zimovanie hají tmavých (Milvus migrans migrans) v Grécku \\ a nové údaje o ich zimovaní inde v Európe
}

\author{
Ivan LITERÁK, David HORAL, Haralambos ALIVIZATOS \& Hynek MATUŠÍK
}

\begin{abstract}
Black kites of the nominal subspecies Milvus migrans migrans breed in the Western Palearctic and in Central Asia, while the European population is relatively small. The birds winter mostly in sub-Saharan Africa. Until 2000 winter observations of black kites were rare in Greece, and also within the tri-point border area of Austria, the Czech Republic and Slovakia. At that time regular wintering of black kites started there. These data and evidence from recent local literature as well as from a number of unpublished data obtained throughout European countries and reviewed in this paper corroborate the impression that numbers of black kites wintering in Europe and the whole Mediterranean area including Turkey are increasing. The reasons considered are climate warming in the area and some negative changes in sub-Saharan Africa in the traditional wintering grounds of black kites. Notes about the wintering of black/red kite hybrids are also added.
\end{abstract}

\begin{abstract}
Abstrakt: Jedince nominálneho poddruhu haje tmavej (Milvus migrans migrans) hniezdia $\mathrm{v}$ západnom Palearkte a v strednej Ázii, pričom Európska populácia je relatívne malá. Zimujú väčšinou v subsaharskej Afrike. Zimné pozorovania hají tmavých boli v Grécku do roku 2000 vzácne, podobne aj v trojhraničí Rakúska, Českej republiky a Slovenska. V tom období tam začalo pravidelné zimovanie haje tmavej. Tieto údaje spolu s informáciami zo súčasných regionálnych publikácií a tiež množstvo nepublikovaných údajov získaných v európskych krajinách a zrešeršované v tomto príspevku vyvolávajú dojem, že počet hají tmavých zimujúcich v Európe a v Stredomorí, vrátane Turecka, stúpa. Môže za tým byt’otepl'ovanie klímy a negatívne zmeny v subsaharskej Afrike v tradičných zimoviskách druhu. V článku sú aj informácie o zimovaní krížencov haje tmavej a haje červenej.
\end{abstract}

Key words: Black kite, Milvus migrans, wintering, migration, Europe

Ivan Literák, Department of Biology and Wildlife Diseases, Faculty of Veterinary Hygiene and Ecology, University of Veterinary and Pharmaceutical Sciences Brno, Palackého tř. 1, 61242 Brno, Czech Republic. E-mail: literaki@vfu.cz (corresponding author).

David Horal, Nature Conservation Agency of the Czech Republic, Regional Office Brno, Kotlářská 51, 60200 Brno, Czech Republic. E-mail: david.horal@seznam.cz.

Haralambos Alivizatos, Hellenic Bird Ringing Center, PO Box 4265, 10210 Athens, Greece. E-mail: xaraaliv@otenet.gr. Hynek Matušík, 68713 Březolupy 324, Czech Republic. E-mail: hynekmb@centrum.cz.

Acknowledgements: We thank the ornithologists from Greece (John Kasvikis, Anastasia Diakou, Maria Katsikatsou, Konstantina Ntemiri, Maria Panagiotopoulou, Kostas Poirazidis, Nikos Probonas, Stefan Schindler, Lavrentis Sidiropoulos and Sylvia Zakkak) and the tri-point border area of Austria, the Czech Republic and Slovakia (Thomas Zuna-Kratky, $†$ Konrad Edelbacher, Michael Bierbaumer, Rainer Raab, Péter Spakovszky, Pavel Štěpánek, Radovan Václav and Boris Maderič) for their data from black kite observations in these areas during winter, and/or for providing us with useful contacts or other help. We thank Lubomír Peške, Radim Petro, Blanka Raab, Rainer Raab and Eugene Shogolev for their cooperation in the field in Greece, Croatia and Italy. We thank Manuel García del Rey and Rita Ferreira for their help with the Spanish and Portuguese literature respectively, and their data about wintering black kites. We thank Guido Ceccolini, Fabienne David, László Haraszthy, Hans Schmid and Aurélie de Seynes for their unpublished data about wintering black kites. We thank Petar Iankov and Stoycho Stoychev (Bulgarian Society for the Protection of Birds/BirdLife Bulgaria), Lyubomir Profirov and Dimitar Ragyov for their valuable information about the situation in Bulgaria. We thank Stanislav Vyhnal for Fig. 6, designed using QGIS free software.

\section{Introduction}

Kites of the nominal subspecies Milvus migrans migrans (Boddaert 1783) (hereafter called black kites) breed in the Western Palearctic and in Central Asia (Ferguson-Lees \& Christie 2001). There exists a relatively small ( $<100,000$ pairs) European population, and 
this declined substantially between 1970 and 1990 (BirdLife International 2004). These birds winter mainly in sub-Saharan Africa, a few remain to winter in the Mediterranean region, and considerably more winter in the Middle East down to southern Arabia (FergusonLees \& Christie 2001). Black kites are opportunistic predators with hunting areas around water bodies, where they feed mostly on fish; on grasslands, where they feed on small mammals, passerines, snakes and invertebrates; and in urban areas, where they look for carrion or waste from abbatoirs and garbage dumps (Panuccio et al. 2013a).

Circannual variations in movement patterns of black kites have been extensively reviewed by Panuccio et al. (2013a). Those authors concluded that black kites are summer residents in Europe and winter mostly in Africa. During migration, tens of thousands of birds are observed migrating across the Straits of Gibraltar, along the eastern side of the Black Sea, and in the Middle East, while substantial numbers cross the central Mediterranean (Italy including Sicily, Tunisia) and the Bosporus. The smallest numbers of birds cross the Mediterranean Sea between the Peloponnese, Crete and Libya.

Panuccio et al. (2013a) also summarized information on wintering black kites. The birds winter in variable densities in sub-Saharan Africa south to Cape Province with the exception of dense forests. Another important wintering area for black kites is the Middle East: the black kite is the most common wintering raptor in Israel, with increasing numbers from the 1980s (Shirihai et al. 2000), and significant concentrations of wintering black kites have appeared in Turkey (Biricik \& Karakaş 2011). Moreover, black kites have begun to winter regularly in Sicily (Sarà 2003). Based on these facts, Panuccio et al. (2013a) called for further research to verify whether observations in the Middle East and Sicily are purely local phenomena, or if the numbers of black kites wintering in the Mediterranean area are possibly increasing in association with a shift of wintering grounds due to climate warming.

Prior to 2000 the European populations of black kites were regarded as strictly migratory, even though the northernmost limit of their irregular wintering encompassed southern Spain, France (including Corsica) and Italy, as well as Germany, Switzerland, Greece, Bulgaria and Romania (Glutz et al. 1971, Ortlieb 1998). Wintering black kites were exceptionally observed in the second half of the 20th century also in Sweden, Poland and Russia (Ortlieb 1998). Recently however, regular wintering of black kites has also emerged in those areas. Here we describe our observations in Greece and within central Europe's tri-point area where the Austrian, Czech Republic and Slovak borders meet, and review new data on observations of black kites wintering elsewhere in Europe.

\section{Material and methods}

De termination of the period of black kite wintering in

E u r o p e

Spring migration of black kites from Africa to Europe towards their breeding territories is the most concentrated across the Straits of Gibraltar, where it starts in the last third of February and peaks during the first half of March (Panuccio et al. 2013a). The second most important flyway goes through the Middle East, where the migration takes place mostly between the second half of March and the first days of April. Rather small numbers of birds migrate across the Bosporus, with a peak in late March. Black kites migrate in low numbers between Tunisia and southern Italy between the last ten days of March and the second third of May. Black kites are virtually absent at watch-sites located on the Adriatic coast of Italy at that time. There are no available data to suggest that in spring the birds cross the eastern part of the Mediterranean Sea to the Balkans (Panuccio et al. 2013a).

During the southwards autumn migration, black kites cross the Mediterranean area again mainly at the Straits of Gibraltar, while substantial numbers also fly through the central and eastern Mediterranean corridors via the straits of Sicily and the Bosporus. A small breeding population believed to exist in Greece crosses the eastern Mediterranean between the Peloponnese, Crete and Libya (Panuccio et al. 2013a). Black kites migrate through the Mediterranean area from July to September, with a few birds also recorded in October (Tanferna et al. 2012, Panuccio et al. 2013a). Birds passing over the Straits of Gibraltar migrate earlier than birds in the central and eastern parts of the Mediterranean area. Based on data from the spring and autumn migrations, we consider all observations of black kites in the period from November until January (and February in the eastern Mediterranean and central Europe) as observations of wintering birds. 
Data relating to wintering b 1 a c k kite s i n E r o p e

Included in this study are long-term data relating to wintering of black kites in the Evros Delta/Dadia-Lefkimi-Soufli Forest National Park (hereafter Dadia NP) in Greece from the years 2002-2017 (and we additionally describe other recent observations of wintering black kites in Greece in January and February), and long-term data relating to wintering by black kites at the tri-point border area of Austria, the Czech Republic and Slovakia (a lowland area with a diameter of about 50 $\mathrm{km}$ from the tri-point where the Morava and Dyje rivers meet) from the years 1997-2017. The data about wintering black kites were obtained directly from our observations and also from a number of local field ornithologists well experienced in the identification of birds of prey.

The River Evros (Maritsa) is the longest river in the Balkans, and is characterized by the large amount of sediment that it transports and deposits in its delta with a total surface area of $188 \mathrm{~km}^{2}$ (Evros Delta 2016). The climate of the Evros Delta area is Mediterranean, although it is affected by continental climate conditions. The Evros Delta constitutes one of the most important wetlands in Europe.

Dadia NP (established in 2003) is situated circa 40 $\mathrm{km}$ NE of the Evros Delta, on its right (Greek) bank. Its altitude varies from 20 to $640 \mathrm{~m}$ a.s.1., and its area is $430 \mathrm{~km}^{2}$. Its landscape is characterized by valleys and hills covered in extensive pine and oak forests (circa $70 \%$ ) as well as a variety of other habitats such as cultivated land, fields, pastures, torrents and stony hills. Dadia NP is considered a local hotspot of biodiversity, containing above all a unique population of raptors (including the only existing black vulture Aegypius monachus colony in the Balkan Peninsula). The Evros Delta and Dadia NP form a crossroads of raptor migration flyways between SE Europe and Asia Minor (Poirazidis et al. 2010).

The tri-point border area of the Czech Republic, Austria and Slovakia is a typical lowland floodplain area (altitude between 140 and $160 \mathrm{~m}$ a.s.1.), formed by a mosaic of floodplain forests (both hardwood with oak and ash being the dominant tree species, and softwood i.e. mainly willow and poplar stands), meadows, arable land and a dense network of water bodies (larger and smaller rivers, oxbow lakes, canals). At the western border of the study area in Austrian territory, important raptor feeding-grounds are situated on a former river terrace (with 20 to $60 \mathrm{~m}$ higher altitude compared to the floodplain itself), with a high proportion of fallow land (partly owing to widespread use of agri-environmental schemes).

All available data from other European countries have also been included in this study. For this purpose, local ornithological literature and personal, until now unpublished data from various local ornithologists well experienced in the identification of birds of prey related to wintering black kites have been reviewed and evaluated. Currently, many data from observations of birds appear in various internet on-line databases. In contrast to data previously published in the literature, using such internet data could lead to biased results. In this paper, only one on-line database was used to help to characterize numbers of black kites wintering in Portugal, Morocco and the Canary Islands.

\section{Results}

Gr e e c e

Black kites have been observed repeatedly during winter in the area of the Evros Delta/Dadia NP in Greece from winter 2002/2003 to winter 2016/2017 (Tab. 1). Roosts of both black kites and red kites (Milvus milvus) were found in central Greece during January 2016. Totals of 65 black kites and and 5 red kites roosted separately in Ochtia $\left(38^{\circ} 38^{\prime} \mathrm{N}, 21^{\circ} 15^{\prime} \mathrm{E}, 26 \mathrm{~m}\right.$ a.s.1.) on January 23 , 2016 (Fig. 1 and 2). The roosts were located in a lowland area among agricultural fields, pastures and orange orchards near a river, an artificial reservoir, and the natural Lake Ozeros. The next day (January 24, 2016), 35 black kites, two red kites and one black/red kite presumed hybrid were seen foraging at a garbage dump near Lagkadi $\left(38^{\circ} 45^{\prime} \mathrm{N}, 21^{\circ} 17^{\prime} \mathrm{E}, 375 \mathrm{~m}\right.$ a.s.1., Fig. 3 and 4) about $14 \mathrm{~km}$ north from the Ochtia roosts. This location was situated in a dry valley among limestone cliffs with patches of small agricultural fields inhabited within and outside of farms by various domesticated animals (Fig. 5). The roosts in Ochtia were checked again on February 28, 2016. Totals of 56 black kites and 6 red kites were then roosting at that location. Moreover, on this day 26 black kites, two red kites and one black/red kite presumed hybrid were seen foraging at the garbage dump near Lagkadi. This observation proved that the kites do indeed winter communally in the area. Next winter the location was checked by Nikos Probonas (unpubl. data) on January 15, 2017, and in the late afternoon of that day 61 black kites and 12 red kites were counted. We checked the location again on January 
Tab. 1. Maximum numbers of observed black kites wintering in Evros Delta/Dadia NP (from December to February) in NE Greece and within the tri-point border area of Austria, the Czech Republic and Slovakia (from November to February).

Tab. 1. Maximálne počty pozorovaných jedincov haje tmavej zimujúcich v delte rieky Evros/NP Dadia (od decembra do februára) v SV Grécku a v rakúsko-česko-slovenskom trojhraničí (od novembra do februára).

\begin{tabular}{lll}
\hline winter / zima & $\begin{array}{l}\text { maximum number of observed birds (date) / najvyšší zaznamenaný počet jedincov (dátum) } \\
\text { the tri-point border area of Austria, the Czech Republic } \\
\text { and Slovakia / rakúsko-česko-slovenské trojhraničie }\end{array}$ \\
\hline $1997 / 1998$ & not studied / nezist'ované & 1 (February 1998) \\
$1998 / 1999$ & not studied & 0 \\
$1999 / 2000$ & not studied & 2 (February 2000) \\
$2000 / 2001$ & not studied & 1 (February 2001) \\
$2001 / 2002$ & not studied & 1 (February 2002) \\
$2002 / 2003$ & 33 (January 22, 2003) & 1 (November, December 2002, January, February 2003) \\
$2003 / 2004$ & 14 (February 21, 2004) & 1 (January 2004) \\
$2004 / 2005$ & 11 (January 13, 2005) & 1 (November 2004, February 2005) \\
$2005 / 2006$ & 0 & 1 (December 2005, January 2006) \\
$2006 / 2007$ & 2 (January 11, 2007) & 1 (December 2006, January, February 2007) \\
$2007 / 2008$ & 0 & 3 (December 2007, January, February 2008) \\
$2008 / 2009$ & 1 (January 22, 2009) & 0 \\
$2009 / 2010$ & 0 & 1 (December 2009, January, February 2010) \\
$2010 / 2011$ & 0 & 1 (February 2011) \\
$2011 / 2012$ & 0 & 2 (January 2012) \\
$2012 / 2013$ & 0 & 1 (November 2012) \\
$2013 / 2014$ & 2 (February 19, 2014) & 0 \\
$2014 / 2015$ & 14 (January 24, 2015) (MBDLSFNP, 2017) & 1 (November, December 2014, January 2015) \\
$2015 / 2016$ & 30 (February 17, 2016) (Zakkak et al. 2017) & 1 (December 2015, January, February 2016) \\
$2016 / 2017$ & 21 (February 28, 2017) (MBDLSFNP, 2017) & 1 (November, December 2016, January, February 2017) \\
\hline
\end{tabular}

Note: Data since 2002/2003 to 2013/2014 are from Evros Delta from Haralambos Alivizatos.

Poznámka: Údaje z rokov 2002/2003 až 2013/2014 sú z delty rieky Evros od Haralambosa Alivizatosa.

30, 2017, and 68 black kites and 6 red kites were found roosting at the same spot as they had roosted the year before. Totals of 67 and 65 black kites were still roosting at this spot on March 5 and March 31, 2017 respectively (Rainer Raab and Blanka Raab, unpubl. data).

Recently black kites were also observed in Greece at other locations as follows: on February 9, 2014 one black kite was observed in the area of the MessolonghiAitoliko Lagoon National Park (John Kasvikis, unpubl. data). On December 13, 2016 three black kites were observed in the industrial area near Alexandropouli $\left(40^{\circ} 51^{\prime} \mathrm{N}, 25^{\circ} 51^{\prime} \mathrm{E}\right)$ (moreover individual black kites or small groups of them could be seen foraging in the area between Feres and Alexandroupoli), in mid-January 2017, 10 black kites and one red kite crossed north of Pefka village $\left(40^{\circ} 54^{\prime} \mathrm{N}, 26^{\circ} 02^{\prime} \mathrm{E}\right)$ near Loutros, and on February 14, 2017 at least 5 black kites were observed at a garbage dump near Xanthi $\left(41^{\circ} 04^{\prime} \mathrm{N}, 24^{\circ} 50^{\prime} \mathrm{E}\right)$ (Lavrentis Sidiropoulos, unpubl. data). On February 2, 2017, 6 black kites and 5 red kites roosted together near Aliartos $\left(38^{\circ} 22^{\prime} \mathrm{N}, 23^{\circ} 08 \mathrm{E}, 98 \mathrm{~m}\right.$ a.s.l.) (our observa- tion), and 2 black kites were also seen at this spot on March 4, 2017 (Rainer Raab and Blanka Raab, unpubl. data). On February 3, 2017 one black kite was observed close to a garbage dump at Mikrolithos $\left(39^{\circ} 47^{\prime} \mathrm{N}\right.$, $22^{\circ} 25^{\prime} \mathrm{E}$ ) near Larissa (our observation). Locations in Greece used for wintering by black kites are shown in Fig. 6 .

The black kite is a scarce migrant in Greece (Panuccio et al. 2013b; Lucia et al. 2011). Greece's black kite population comprised 5-20 breeding pairs during 1995-2000 (BirdLife International 2004). In winter, black kites were rare and local in Greece. When seen, they were almost always found in or near wetlands (Handrinos and Akriotis 1997). Even if black kites were observed wintering in Greece from November to February in the past (Makatsch 1948), it seems that the dozens of black kites now wintering in Greece represent a new phenomenon. The newly-observed black kites wintering in Greece prefer lowland habitats near water bodies and use garbage dumps as a source of food in central Greece as well as in the Evros Delta/Dadia NP area. 

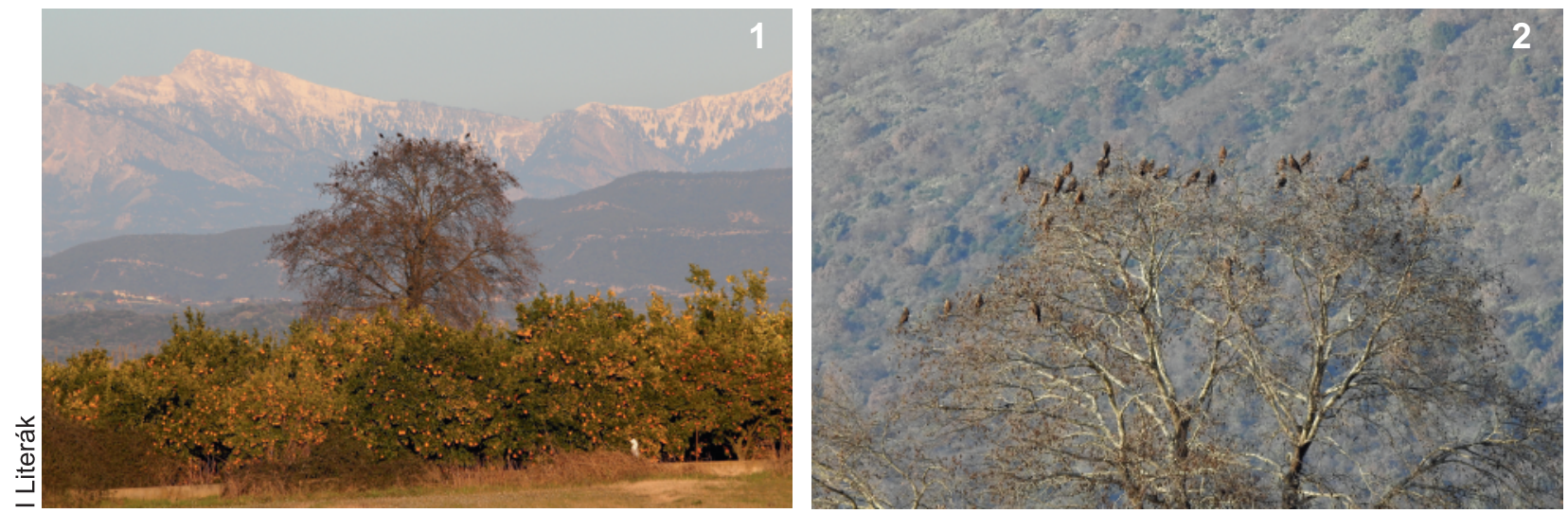

Fig. 1-2. Black kites roosting near Ochtia, Greece in winter 2015/2016.

Obr. 1 - 2. Haje tmavé nocujúce pri Ohtii, Grécko, v zime 2015/2016.
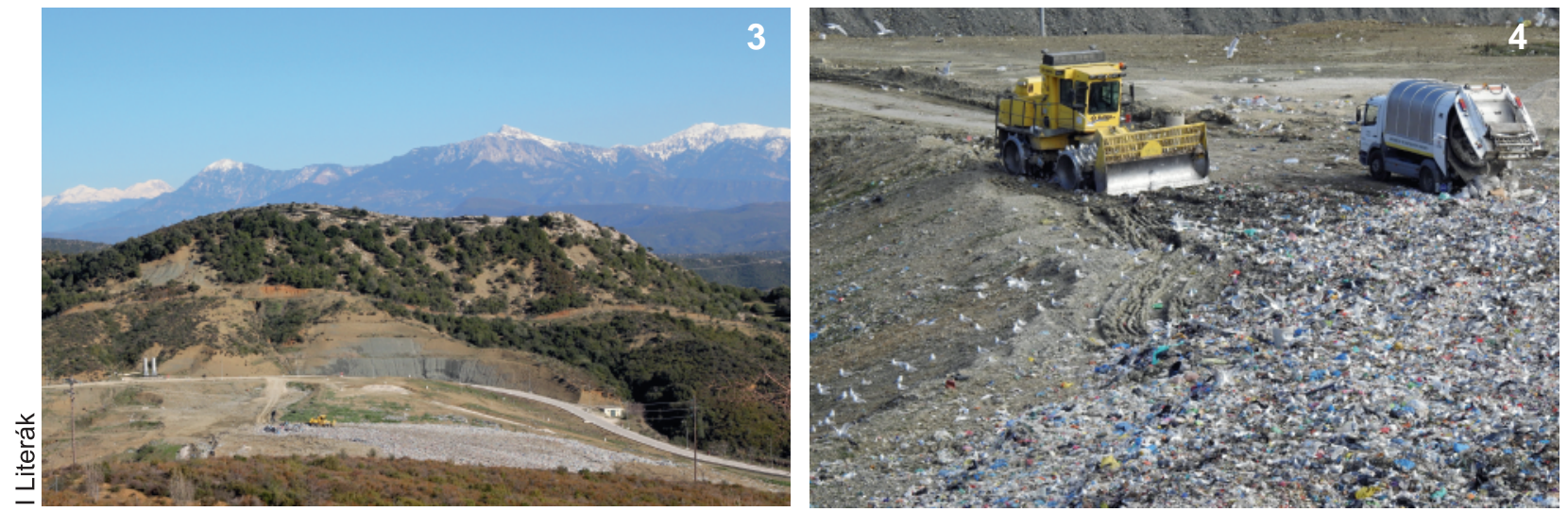

Fig. 3-4. Garbage dump near Lagkadi, Greece where black kites roosting near Ochtia were usually foraging (3); detail view with a number of gulls foraging here with black kites, red kites and other birds (4).

Obr. 3 - 4. Smetisko pri Lagkadi, Grécko, kde haje tmavé od Ohtie zvyčajne hl'adali potravu (3); pohl'ad na množstvo čajok hladajúcich tu potravu spolu s hajami tmavými, červenými a inými druhmi vtákov (4).

\section{O t h e r c o u n t rie s}

From winter 1997/1998 until the present, black kites have wintered regularly in the tri-point border area of Austria, Czech Republic and Slovakia, totalling one to three birds wintering nearly every year (Tab. 1). Winter observations of black kites had been rare in this tri-point border area until 2000, with only exceptional sightings in 1959, 1983 and 1988 (Horák \& Horal 2002, 2004). Since the winter of $1999 / 2000$, regular wintering by dozens of red kites in a communal roost has appeared in the area (up to 100 birds). In the post-breeding period and during the autumn passage (August-November), a communal roost of up to 140 birds has existed regularly in the same area since 1993. It has been postulated that the winter occurrence of black kites was connected with roosting red kites. The soaring flocks of red kites probably attracted the black kites (Horák \& Horal 2004). We assume that communally roosting red kites initialized the choice of the area as a roost for black kites as well, which themselves had to find the area suitable from various aspects for their regular wintering in subsequent years.

On March 2, 2017, Hynek Matušík observed a kite gliding over the Košárské louky meadows near Lanžhot, Czech Republic $\left(48^{\circ} 38^{\prime} \mathrm{N}, 16^{\circ} 56^{\prime} \mathrm{E}\right)$ within the tri-point border area. This kite looked like black kite with a particularly contrasting wing pattern (Fig. 7). We consider it as a hybrid between black and red kites, because it showed the characteristics of both parent species. 


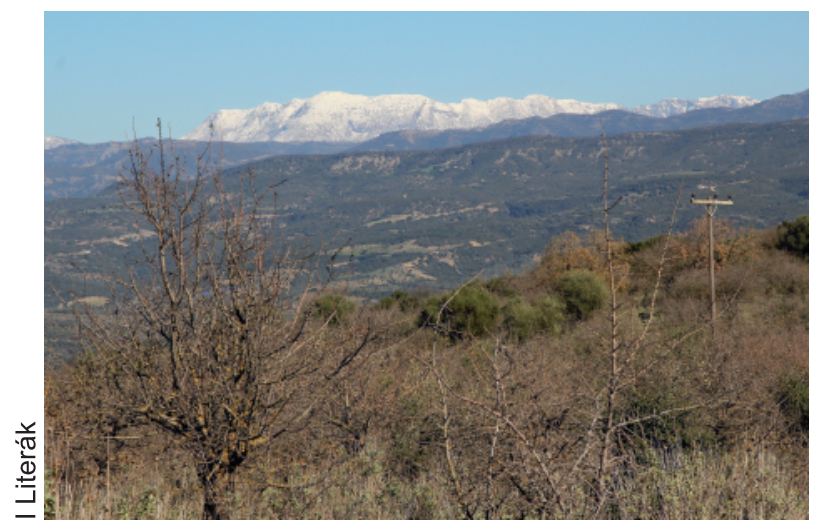

Fig. 5. Landscape near Agrinio, central Greece, used by black kites for wintering. The roosting place near Ochtia and garbage dump near Lagkadi are situated in this area.

Obr. 5. Krajina pri Agriniu, stredné Grécko, využívaná hajami tmavými ako zimovisko. Nocovisko pri Ochtii a smetisko pri Lagdaki sú v tomto území.

Recently black kites have wintered commonly in Spain (Palomino 2012, Mayordomo et al. 2015) and sometimes dozens to hundreds of black kites have been observed in winter foraging on rubbish dumps (Molina et al. 2012). It seems that wintering by black kites in Spain is now much more common than earlier (Franco \& Amores 1980, Sunyer \& Viñuela 1994). Similarly in Portugal, the occurrence of black kites in December and January was formerly considered very rare (Catry et al. 2010). Nevertheless, some recent data about wintering black kites (meaning in these cases birds observed in December and January) in Portugal, Morocco and the Canary Islands are available from the eBird database (eBird 2016). In the period from 1900 to 2000, there was only one winter observation of a black kite registered in Portugal, and no observations were recorded from Morocco and the Canary Islands. In the period 2001-2016, totals of about 33, 7 and 2 black kites were documented wintering in Portugal, Morocco and the Canary Islands, respectively.

In Switzerland, which has a well-established birdobserver network, data about wintering black kites have been available since the 1980s (Hans Schmid, Swiss Ornithological Institute, unpubl. data). Wintering had been unknown until 2002/2003, when for the first time a black kite was recorded within a roost of red kites near Bern. A second record followed near Zurich in the winter of 2011/2012. During that same winter, a third bird started a tradition of overwintering at a feeding site near Lucerne. The same bird has most probably been seen every winter since, including during the 2015/2016

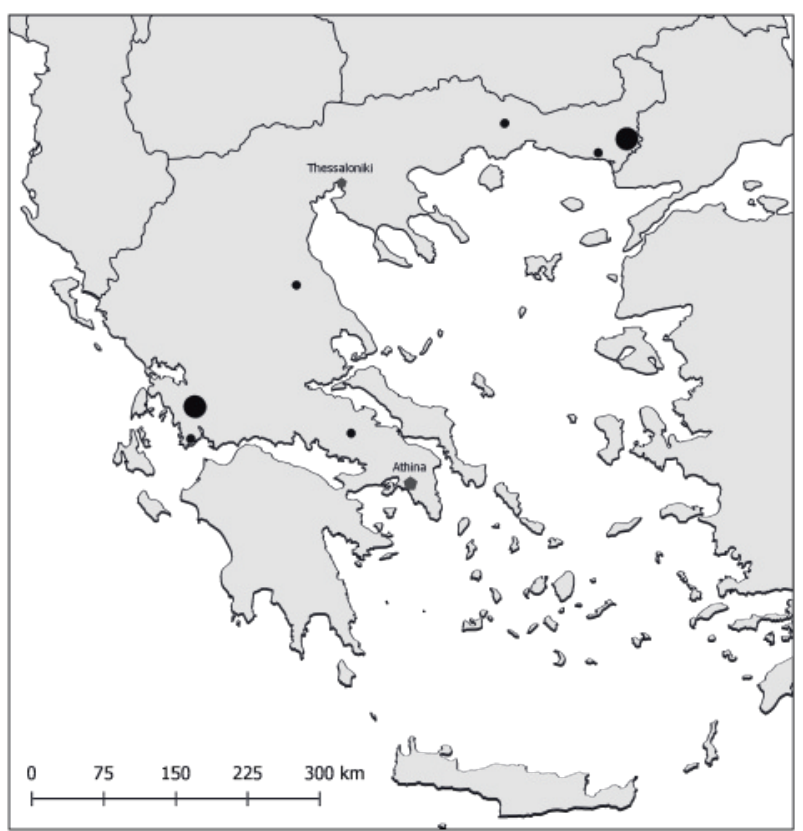

Fig. 6. Locations in Greece used recently for wintering by black kites (big dots - dozens of wintering black kites, small dots - individual birds or groups of up to 10 birds).

Obr. 6. Lokality v Grécku v súčasnosti využívané ako zimoviská hají tmavých (vel'ké body - tucty zimujúcich hají tmavých, malé body - jednotlivé vtáky alebo skupiny do 10 jedincov).

season. In addition, there is a tendency for more and more black kites to appear in November, as there are now 11 records since 2000 compared to only one previously. As the first migrants already arrive early (in February) in Switzerland, it is impossible to discern a similar trend separately for late winter.

Observations of wintering black kites in France too have been less rare in recent years. For example, one black kite wintered during 2013/2014 and again one during 2014/2015 together with red kites at roosting places in the foothills of the Pyrenees (Benjamin Bouthillier, unpubl. data), and 11 and 6 black kites were registered during January 2016 and January 2017 respectively, as revealed in the census of red kites (Fabienne David and Aurélie de Seynes, French Red Kite Network, unpubl. data). Moreover, one black/red kite presumed hybrid was observed during January 2017, again according to the census of red kites (Fabiene David, unpubl. data, and The red kite 2017). These data are indicative of a recently increasing number of wintering black kites also in that part of Europe.

The process of black kite colonization in Sicily, Italy has been well documented (Sarà 2003). It seems that the 
first step in the colonization of Sicily by black kites involved breeding, later followed by their presence in winter, and finally by their presence in summer (establishment of a summer roost). The first recorded overwintering of black kites in Sicily occurred during four years (1987-1990) of severe drought and warm winters, and from 1990 black kites have regularly wintered in Sicily. In continental Italy (Guido Ceccolini, unpubl. data), no black kites wintered in the southern part of Tuscany until 2009. Together with the re-establishment of a local red kite population during 2007-2014 (Save the flyers 2017), black kites also began wintering regularly in this area. One to four black kites were observed there during each winter from 2009 to 2016 (i.e. 2015/2016). Moreover, 6 black kites and 12 red kites were observed supposedly wintering at the garbage dump near San Brancato $\left(40^{\circ} 13^{\prime} \mathrm{N}, 16^{\circ} 17^{\prime} \mathrm{E}\right)$ on 14 February 2017 (Rainer Raab, unpubl. data).

Croatia is situated outside of the migration routes for black kites, and no wintering black kites had been observed there in the past (Tutiš et al. 2013). Wintering black kites were first observed in the north-eastern part of Croatia (Baranje) in the winters 2014/2015 and $2015 / 2016$, both seasons at the same location in Jagodnjak $\left(45^{\circ} 42^{\prime} \mathrm{N}, 18^{\circ} 34^{\prime} \mathrm{E}, 85 \mathrm{~m}\right.$ a.s.l.) (Ivan Literák, Hynek Matušík, Lubomír Peške, Radim Petro, unpubl. data). One black kite was recorded on 26-27 January 2015 together with 7 red kites, and one black kite on January 21,2016 . The birds were observed on a rubbish dump near a village. Agricultural fields and forest patches were present around the village, with carrion of domesticated animals and game available as food for the kites.

Some black kites have in the past stayed to overwinter in Bulgaria. For example there is a museum specimen there from early February (Patev 1950). Kumerloeve (1956) mentioned December and January records from Plovdiv and Nova Zagora in the extremely harsh winter of 1941/42, and Baumgart (1971) has one observation from Sliven in early February 1962. During the winter months single individuals have been registered very rarely in the lowlands, while early-February records are more frequent (Simeonov et al. 1990). Moreover, Petar Iankov (unpubl. data) observed one black kite near the River Ropotamo on the south-eastern Black Sea coast in January during the 1980s, and one black kite near Alepu Marsh on the southern Black Sea coast on January 17, 1993. Recent sources, such as Golemanski (2011), nevertheless define the species

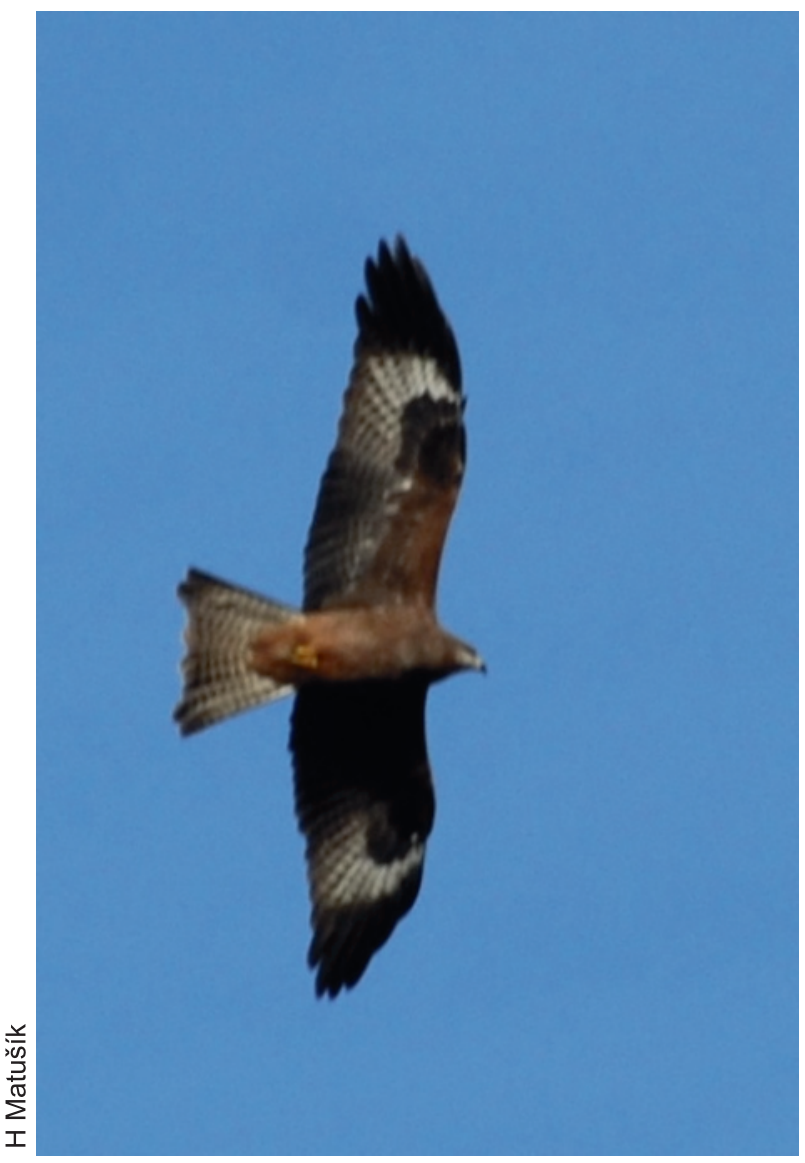

Fig. 7. A black/red kite presumed hybrid observed at Košárské louky meadows near Lanžhot, Czech Republic on March 2, 2017

Obr. 7. Pravdepodobne hybridný jedinec haje tmavej a červenej pozorovaný na Košárskych lúkach pri Lanžhote, Česká republika, 2. marca 2017.

status as a breeding summer visitor, passage migrant and partly winter visitor, because the number of winter records increased after 2000. Stoychev et al. (2008) report two observations in the Sakar Mountains, both near the River Maritsa (Lyubimets, January 2000; Harmanli, December 2006). Meanwhile, Lyubomir Profirov (unpubl. data) relates two observations from the northeastern Black Sea coast, as a juvenile stayed near Lake Durankulak for several days in February 2005, and one adult bird was recorded on February 4, 2011 near the village of Gorun in north-eastern Bulgaria. In early February 2015 a black kite was also found at Burgas Lakes (Iankov 2015). In that author's opinion, this observation confirms the trend towards a winter presence of this formerly typical migrant. The highest-ever winter 
number of black kites (seven birds, along with five red kites) was observed in Bulgaria during January 2015 in the Upper Thracian Plain (Anonymous 2015).

Black kites were formerly characterized as sporadically wintering in Turkey, and there are records from all regions of Turkey (Kirwan et al. 2008). An exceptionally large group of 100 roosting birds observed near the River Seyhan in the Mediterranean area on $11 \mathrm{Feb}$ ruary 1996 was assumed to consist of either very early migrants or a significant wintering concentration. Recently a common wintering of black kites was described in south-eastern Anatolia, Turkey (Biricik \& Karakaş 2011). The region with wintering kites is characterized by dry valleys with patches of steppe and agricultural fields interspersed with limestone cliffs, which is similar to the area where we found the birds in central Greece. Wintering black kites were observed at several locations in winters from 2001 to 2011. Most of these were recorded at garbage dumps where household waste was deposited, and around slaughterhouses where various parts of slaughtered animals were available. In December 2007 more than 1,200 (the highest number counted) black kites wintered near Gaziantep-Oğuzeli. It was estimated that at least 7,500 black kites wintered in the area during 2011. Those authors were not able to state whether such large wintering numbers constituted a recent novelty, or if kites had wintered there in the past and simply gone undetected. We suppose that the first variant is the more likely, because only exceptionally had wintering black kites been observed in the past in the Middle East including Turkey, Syria and Lebanon (Kumerloeve 1967). Common observations of wintering black kites in Israel which are in contrast to the past (Shirahai et al. 2000) and some recent observations of wintering black kites in Egypt (Ciach \& Kruszyk 2010) lend support to this idea.

In Ukraine, wintering black kites have been observed since 1998 . The number of wintering black kites has risen to as many as 70 birds in the Danube Delta and Southern Crimea, where they often use communal garbage dumps for foraging (Tsvelykh \& Panjuskhin 2002). Moreover, one black kite was observed in January 2009 on a garbage dump near Kyiv (Domashevsky 2009). These observations coincided with recent observations of wintering black kites in Hungary, where the birds were seen individually in January 2010, January 2011, January 2012 and January 2016 during the period 2010-2016 (László Haraszthy, unpubl. data).

\section{Discussion}

The process of black kite colonization in Sicily (Sarà 2003) and the growing number of wintering birds in continental Europe documented above (see also Tab. 2) and reportedly Turkey as well (Biricik \& Karakaş 2011), coincides with climate warming in Europe. According to key findings of the European Environmental Agency (EEA 2013), the period 2002-2011 was the warmest on record in Europe, with the European land temperature being $1.3^{\circ} \mathrm{C}$ warmer than the pre-industrial average. Various model projections show that Europe could be $2.5-4{ }^{\circ} \mathrm{C}$ warmer in the later part of the $21^{\text {st }}$ century compared to the 1961-1990 average. It is evident that winters are milder and that some bird species respond to the climate warming by shifting their breeding and wintering areas northwards. An analysis of long-term population growth rates in European passerines has documented simultaneous responses that can be attributed to both climate warming and land-use change. These include long-term increase in populations of thermophilic species as well as decline in long-distance migrants and farmland specialists (Jørgensen et al. 2015). European passerines were found to be affected by winter, spring and summer conditions, depending on the distinct breeding phenology corresponding to their migratory strategy. We suppose that, similarly to some species of European passerines, black kites could benefit from higher temperatures in European wintering areas. Moreover, it seems that access to open garbage dumps as a source of food across the whole Mediterranean area has facilitated the survival of wintering black kites.

Recently a long-term dataset (1980-2010) of seven partial migrant raptor species in five European regions has been analyzed, and it was revealed that the responses of these birds to climate-induced changes are abrupt and synchronous on a continental scale (Jaffré et al. 2013). It was found that as the temperatures increased, the birds delayed their mean passage date of autumn migration. This delay, in addition to earlier spring migration, suggests that significant warming may induce an extension of the breeding-area residence time of migratory raptors, which may eventually lead to residency. This scenario could also be true for black kites, and could explain the changes in winter behaviour of black kites observed in our study.

It has been reported that the breeding behaviour of black kites in Italy responded quickly to climate warming (Sergio 2003). Black kites in Europe breed mostly where the sum of annual temperature exceeds circa 


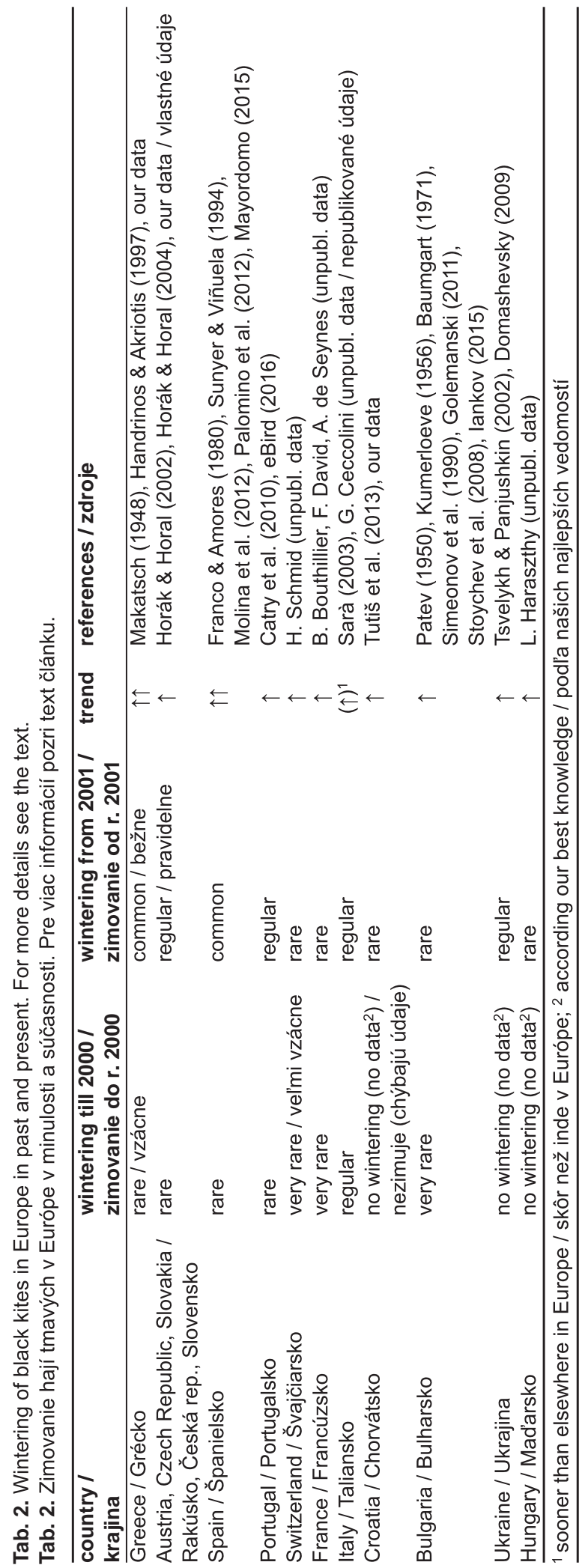

1,500 degree-days above $5{ }^{\circ} \mathrm{C}$ (Huntley et al. 2007). The future potential distribution according to predictions based upon expected climate warming is shifting northwards, such that southern England and southern Fennoscandia will become suitable even as many southern parts of the present range will become unsuitable (Huntley et al. 2007).

Similarly to the change in black kites' breeding behaviour due to climate warming, we suppose that climate warming in Europe is one of the reasons responsible for the new phenomenon of black kite wintering in the Mediterranean area, central Europe, and possibly elsewhere in Europe. Additional reasons could be negative changes in sub-Saharan Africa, such as increasing density of human population and extensive use of pesticides. Large nomadic swarms of locusts are major food sources for wintering kites in the Sahel, and aerial and ground spraying of insecticides often wipes out this resource and indirectly kills many kites (Panuccio et al. 2013a). Moreover, the Sahel as an important area for wintering black kites has been degraded during recent decades by severe droughts, which could adversely affect the wintering populations of black kites (Cortéz-Avizanda et al. 2011).

Potential risks experienced by the wintering population include illegal hunting, carcass poisoning and declining food availability caused by new sanitary regulations affecting the processing and exposure of garbage within dumps (Biricik \& Karakaş 2011). An advantage, on the other hand, is that the costs for migration are probably much lower for birds wintering in Europe than for birds wintering in sub-Saharan Africa. Moreover, birds wintering in Europe can reach their breeding territories earlier than other birds, and this improves their chances of occupying the best-quality sites for breeding. Hence, they pay no cost for migration and they are the first to arrive at the nesting territories. That this constitutes an advantage for their breeding success seems to be obvious, because older and more experienced black kites defend their breeding territories better than younger ones. The quality of their breeding territory is therefore strongly correlated with the date of settlement. Annual breeding performance is known to be better in high-quality than in low-quality sites (Sergio \& Newton 2003, Sergio et al. 2007, Sergio et al. 2009).

Hybrids of black kites and red kites are produced by mixed pairs in the area of their sympatric occurrence (Heneberg et al. 2016). Recently, for example, such cases have been documented in Belarus, the Czech Republic and Slovakia (Literák et al. 2014, Mindlin 2015). 
Where the hybrids winter is basically unknown. A kite photographed in Kenya in March 1987 was lately identified as a black/red presumed hybrid (Frere 1987, Bijlsma 1988).

In January 1999 an adult black/red kite hybrid was observed in southern Italy (Corso \& Palumbo 2001). A black/red kite presumed hybrid was observed in England in January and February 2003 (Woolley 2004). In October 2006 a juvenile hybrid was observed in Cyprus (Forsman \& Nye 2007). Three cases more of black/red kite presumed hybrids wintering in Europe (Greece, France, Czech Republic) were mentioned in this paper above. Usually black kites winter in sub-Saharan Africa, while red kites winter in Europe. It seems that most hybrids stay to winter in Europe, even if at least one of them has been observed in sub-Saharan Afrika.

C o n c l u s i o n s

Our data from Greece and the tri-point border area of Austria, the Czech Republic and Slovakia and evidence from recent local literature as well as from a number of unpublished data obtained throughout European countries and reviewed in this paper together corroborate the impression that numbers of black kites wintering in Europe and the whole Mediterranean area including Turkey are increasing (Tab. 2). The reasons considered are climate warming in the area and some negative changes in sub-Saharan Africa in the traditional wintering grounds of black kites.

\section{References}

Anonymous 2015: Otkrito novo miasto za vremenno prebivavane na tsarski orli I drugi redki vidove [New temporary settlement area of imperial eagles and other rare species discovered]. Retrieved March 29, 2016, from http://bspb.org/bg/news/Otkritonovo-miasto-za-vremenno-prebivavane-na-tsarskiorli-i-drugi-redki-vidove.html. [in Bulgarian]

Baumgart W 1971: Beitrag zur Kenntnis der Greifvögel Bulgariens. Beitrage zur Vogelkunde 17: 33-70.

Bijlsma RB 1988: Unidentified Kenyan kites - hybrid black $\times$ red? GABAR 3: 19-20.

BirdLife International 2004: Birds in Europe: population estimates, trends and conservation status. BirdLife Conservation Series No. 12. BirdLife International, Cambridge, 374.

Biricik M \& Karakaş R 2011: Black kites (Milvus migrans) winter in Southeastern Anatolia, Turkey. Journal of Raptor Research 45: 370-373.
Catry P, Costa H, Elias G \& Matias R 2010: Aves de Portugal - Ornitologia do território continental [Birds of Portugal - Ornithology in mainland territory]. Assírio and Alvim, Lisbon, 944. [In Portugal]

Ciach M \& Kruszyk R 2010: Foraging of white storks Ciconia ciconia on rubbish dumps on non-breeding grounds. Waterbirds 33: 101-104.

Corso A, Palumbo G 2001: Prima osservazione italiana di ibrido tra Nibio reale Milvus milvus e Nibio bruno Milvus migrans [The first observation in Italy of a red kite Milvus milvus and black kite Milvus migrans hybrid]. Picus 27: 31-33. [in Italian]

Cortéz-Avizanda A, Almaraz P, Carrete M, Sánchez-Zapata JA, Delgado A, Hiraldo F \& Donázar JA 2011: Spatial heterogeneity in resource distribution promotes facultative sociality in two trans-Saharan migratory birds. PLoS ONE 6(6): e21016.

Domashevsky SV 2009: Pervaya registraciya chernogo korshuna $\mathrm{v}$ zimniy period na severe Ukrainy [First record of the black kite in winter in the northern part of Ukraine]. Berkut 18: 212-213. [in Russian with English summary]

eBird 2016: Welcome to eBird. Birding in the $21^{\text {st }}$ Century. Retrieved April 3, 2016, from http://www.ebird.com/explore

EEA (European Environmental Agency) 2013: Climate change evident across Europe, confirming urgent need for adaptation. Retrieved January 30, 2016, from http://www.eea.europa.eu/media/newsreleases/climate-change-evident-across-europe

Evros Delta 2016: General description. Retrieved September 19, 2016, from http://www.evrosdelta.gr/en/evros-delta/general-description.

Ferguson-Lees J \& Christie DA 2001: Raptors of the world. Helm identification guides. Christopher Helm, London, 992.

Forsman D, Nye D 2007: A hybrid red kite $\times$ black kite in Cyprus. Birding World 20: 480-481.

Franco A \& Amores F 1980: Observación invernal de Milvus migrans en la Península Ibérica [Winter observation of Milvus migrans in the Iberian Peninsula]. Acta Vertebrata (Doñana) 7: 266. [in Spanish]

Frere PJ 1987: Unidentified Milvus kites in Kenya. Growth and Biology of African Raptors 2: 47-48.

Glutz von Blotzheim UN, Bauer K \& Bezzel E 1971: Handbuch der Vögel Mitteleuropas. Bd: 4: Falconiformes. Akademische Verlagsgesellschaft, Wies- 
baden, 629 .

Golemanski V et al. 2011: Red data book of the Republic of Bulgaria. Volume 2. Animals. IBEI - BAS \& MOEW, Sofia, 173.

Heneberg P, Dolinay M, Matušík H, Pfeiffer T, Nachtigall W, Bizos J, Šimčíková D \& Literák I. 2016: Conservation of the red kite Milvus milvus (Aves: Accipitriformes) is not affected by the establishment of a broad hybrid zone with the black kite Milvus migrans migrans in central Europe. PLoS ONE 11(7): e0159202. DOI: 10.1371/journal.pone.0159202

Iankov P 2015: Unusual winter records in Burgas area. Retrieved March 29, 2016, from http://bspb.org/poda/en/rare-visitors.html.

Jaffré M, Beaugrand G, Goberville É, Jiguet F, Kjellén N, Troost G, Dubois PJ, Lepretre A \& Luczak C 2013: Long-term phenological shifts in raptor migration and climate. PLoS ONE 8(11): e79112. DOI:10.1371/journal.pone.0079112

Handrinos G. \& Akriotis T 1997: The Birds of Greece. Christopher Helm, London, 336.

Horák P \& Horal D 2002: Časný př́let luňáka hnědého (Milvus migrans) na jižní Moravu [The early arrival of black kite (Milvus migrans) in South Moravia]. Crex 18: 21-22. [in Czech with English summary]

Horák P \& Horal D 2004: Zimní výskyt luňáka hnědého (Milvus migrans) na jižní Moravě a ve východním Rakousku [Wintering of the black kite (Milvus migrans) in Southern Moravia and Eastern Austria]. Crex 23-24: 41-43. [in Czech with English summary]

Huntley B, Green RE, Collingham Y \& Willis SG 2007: A climate atlas of European breeding birds. Durham University, RSPB and Lynx Edicions, Durham, Sandy and Barcelona, 521.

Jørgensen PS, Böhming-Gaese K, Thorup K, Tøttrup AP, Chylarecki P, Jiguet F, Lehikoinen A, Noble DG, Reif J, Schmid H, Van Turhnout C, Burfield IJ, Foppen R, Voříšek P, Van Strien A, Gregory RD \& Rahbek C 2016: Continent-scale global change attribution in European birds - combining annual and decadal time scales. Global Change Biology 22: 530-543. DOI: $10.1111 / \mathrm{gcb} .13097$.

Kirwan GM, Boyla KA, Castell P, Demirci B, Özen M, Welch H \& Marlow T 2008: The birds of Turkey. The distribution, taxonomy and breeding of Turkish birds. Christopher Helm, London, 512.

Kumerloeve H 1956: Der Schwarzmilan als Wintergast in Bulgarien. Vogelwelt 77: 2.

Kumerloeve H 1967: Vom Überwintern des Schwarzmilan in Vorderen Orient. Falke 14: 274-275.

Literák I, Matuš́k H, Rác P 2014: Luňáci, jejich variabilita a hybridizace [Kites, their intra- and interspecies variability and interspecies hybridization]. Živa 62: 35-39. [in Czech with English summary]

Lucia G, Agostini N, Pannucio M, Mellone U, Chiatante G, Tarini D \& Evangelidis A 2011: Raptor migration at Antikythira, in southern Greece. British Birds 104: 266-270.

Makatsch W 1948: Der Schwarze Milan als Wintergast in Griechenland. Ornithologische Berichte 1: 143-145.

Mayordomo S, Prieta J \& Cardalliaguet M 2015: Aves de Extremadura, vol. 5, 2009-2014. Retrieved April 7, 2016, from http://birds-extremadura.blogspot.com.

MBDLSFNP (Management Body of Dadia-LefkimiSoufli Forest National Park) 2017: Monitoring database of species and habitats (raw data). Retrieved March 22, 2017.

Mindlin G. 2015: Krasnoye i chernoye [Red and black]. Ptushki i My. 26: 9. [in Russian]

Molina B, Prieta J \& Lorenzo JA 2012: Noticiario ornitológico [Ornithological rarities]. Ardeola 59: 167-194. [in Spanish]

Ortlieb R 1998: Der Schwarzmilan. Die Neue BrehmBücherei Bd. 100. Westarp Wissenschaften, Hohenswarsleben, 176.

Palomino D 2012: Milano negro Milvus migrans [Black kite Milvus migrans], 162-163. In SEO/BirdLife: Atlas de las aves en invierno en España 2007-2010 [Atlas of birds wintering in Spain 2007-2010]. Ministry of Agriculture, Food and the Environment, Spanish Ornithological Society/BirdLife, Madrid, 817. [in Spanish]

Panuccio M, Agostini N, Mellone U \& Bogliani G 2013a: Circannual variation in movement patterns of the black kite (Milvus migrans migrans): a review. Ethology, Ecology and Evolution 26: 1-18.

Panuccio M, Agostini N \& Barboutis C 2013b: Raptor migration in Greece: a review. Avocetta 37: 1-7.

Patev P 1950: Pticite v Balgarija [Birds of Bulgaria]. BAN Publishing, Sofia, 364. [in Bulgarian]

Poirazidis K, Kati V, Schindler S, Kalivas D, Triantakonstantis D, Gatzogiannis St. 2010: Landscape and biodiversity in Dadia-Lefkimi-Soufli Forest National Park; 103-114. In: Catsadorakis G \& 
Källander H (eds), The Dadia-Lefkimi-Soufli National Park, Greece: biodiversity, management and conservation. WWF Greece, Athens, 114.

Sarà M 2003: The colonization of Sicily by the black kite (Milvus migrans). Journal of Raptor Research 37: 167-172.

Save the flyers 2017: LIFE Save the flyers. Measures for conservation of Chiroptera and Avifauna in Central Italy. Retrieved March 30, 2017, from www.lifesavetheflyers.it.

Sergio F 2003: Relationship between laying dates of black kites Milvus migrans and spring temperatures in Italy: rapid response to climate change? Journal of Avian Biology 34: 144-149.

Sergio F, Blas J, Forero MG, Donázar JA \& Hiraldo F 2007: Sequential settlement and site dependence in a migratory raptor. Behavioural Ecology 18: 811-821.

Sergio F, Blas J \& Hiraldo F 2009: Predictors of floaters status in a long-lived bird: a cross-sectional and longitudinal test of hypotheses. Journal of Animal Ecology 78: 109-118.

Sergio F \& Newton I 2003: Occupancy as a measure of territory quality. Journal of Animal Ecology 72: 857-865.

Shirahai H, Yosef R, Alon D, Kirwan GM \& Spaar R 2000: Raptor migration in Israel and the Middle East. International Birdwatching Centre Eilat, IBRCE, IOC, SPNI, Eilat, 192.

Simeonov SD, Michev TM \& Nankinov DN (eds) 1990: Fauna na Balgarija 20, Aves Vol. 1 [Fauna of Bulgaria]. BAN Publishing, Sofia, 350. [in Bulgarian].
Stoychev S, Demerdzhiev D, Gerdjikov G \& Borisov B 2008: The Birds of the Sakar Mountain. Tourist Association Astrea, Haskovo, 56.

Sunyer C \& Viñuela J 1994: Invernada de rapaces (O. Falconiformes) en España peninsular e Islas Baleares [Wintering of raptors (O: Falconiformes) in the Spanish Peninsula and the Balearic Island], 361-370. In Muntaner J \& Mayol J (eds), Biología y Conservación de las Rapaces Mediterráneas [Biology and conservation of Mediterranean raptors]. SEO/BirdLife, Madrid, 488. [in Spanish]

The red kite 2017: La LPO et les rapaces. Retrieved March 30, 2017, from rapaces.lpo.fr/en/milan-royal.

Tsvelykh AN \& Panjushkin VE 2002: Zimovki chernogo korshuna (Milvus migrans) v Ukraine [Wintering of the black kite (Milvus migrans) in Ukraine]. Vestnik Zoologii 36: 81-83. [in Russian with English summary]

Tutiš V, Kralj J, Radović D, Ćiković D \& Barišič S 2013: Crvena knjiga ptica Hrvatske [Red data book of birds of Croatia]. Ministry of Environmental and Nature Protection, Zagreb, 258. [in Croatian]

Woolley S 2004: An unusual kite at Cheesefoot Head in early 2003. Hampshire Bird Report, November 2004 (2005): 215-219.

Zakkak S, Babakas P, Chalivelentzios A \& Tziambazis I. 2017: Anual monitoring report on species and habitats of European concern - 2016. Management Body of Dadia-Lefkimi-Soufli Forest National Park. Dadia Evros, 47. 